\title{
Article 23. Technology Transfer, Collaboration and Cooperation
}

In accordance with Articles 15, 16, 18 and 19 of the Convention, the Parties shall collaborate and cooperate in technical and scientific research and development programmes, including biotechnological research activities, as a means to achieve the objective of this Protocol. The Parties undertake to promote and encourage access to technology by, and transfer of technology to, developing country Parties, in particular the least developed countries and small island developing States among them, and Parties with economies in transition, in order to enable the development and strengthening of a sound and viable technological and scientific base for the attainment of the objectives of the Convention and this Protocol. Where possible and appropriate such collaborative activities shall take place in and with a Party or the Parties providing genetic resources that is the country or are the countries of origin of such resources or a Party or Parties that have acquired the genetic resources in accordance with the Convention.

\section{Overview}

Technology transfer is an essential form of benefit-sharing ${ }^{1}$ and a key means to contribute to the conservation and sustainable use of biodiversity. ${ }^{2}$ It was part of the grand bargain struck in the negotiations of the $\mathrm{CBD}$, and considered an essential counterpart to provisions related to access to genetic resources: access is to be balanced against greater availability of scientific and technological information and environmentally sound technology that make use of these resources. ${ }^{3}$ Technology transfer is thus seen as a means to acknowledge and reward the contribution of countries, as well as indigenous and local

1 Greiber et al., Explanatory Guide, op. cit., 216.

2 See this commentary on Article 1, section 4. On the holistic interpretation of the three СвD objectives in the context of the Protocol, see also this Article 5, section 6; Article 8, section 2; Article 9, section 2; Article 10, section 4; Article 12, section 5; Article 21, section 3; and Article 22, section 3.

3 See Glowka, Burhenne-Guilmin and Synge, Guide to the Convention on Biological Diversity, op. cit., 84; and Greiber et al., Explanatory Guide, op. cit., 215. 
communities, providing genetic resources and traditional knowledge to the development of related technologies. ${ }^{4}$

While technology transfer and scientific collaboration may take place in the context of specific ABS transactions, and be set out in MAT, ${ }^{5}$ the scope of Article 23 goes beyond bilateral ABS relationships. It includes any type of inter-governmental cooperation and collaboration such as joint research programmes that may involve ABs-related activities.

The main legal complexity related to Article 23 , as anticipated in the opening provision of the Protocol, ${ }^{6}$ concerns the limitation of State efforts in sharing technology that is in the hands of private actors, particularly when protected by IPRs. This is a complexity that is common to other MEAs. ${ }^{7}$ The following sections will thus analyse in the light of the reticence of the Protocol negotiators to address WTO law- and IPR-related matters ${ }^{8}$ the obligation to cooperate in the area of technology, and the obligation related to technology transfer, in turn.

\section{Technology Collaboration and Cooperation}

Article 23 establishes an obligation for Parties to collaborate and cooperate in technical and scientific research, and development programmes, including biotechnological research activities. The obligation is clear but quite openended. It requires States to enter into negotiations without specifying the possible avenues for pursuing them - at the bilateral, regional or multilateral level. The obligation does not go as far as requiring States to reach agreement, so if agreement cannot be reached, they are not prevented from making unilateral determinations about technical and scientific research. In doing so,

4 Ibid., 216-7.

5 See generally this commentary on Article 5 section 5; and also on Article 6, section 7 and on Article 18.

6 See reference to 'taking into account all rights... to technologies' in Protocol Article 1. See this commentary on Article 1, section 2, fn. 8.

7 See for example Birnie, Boyle and Redgwell, International Law and the Environment, op. cit., 134; and UNE P-UNCTAD, A Preliminary Analysis of MEA Experiences in Identifying and Facilitating the Transfer of Technology (Nairobi and Geneva: UNEP-UNCTAD, 2007), accessed 30 November 2013, <www.unep.ch/etb/areas/pdf/MEA\%20Papers/MEA_EGS\%20Paper. pdf $>$.

8 See generally Pavoni, "Nagoya Protocol and wTo Law," op. cit. 
however, Parties should take in consideration other Parties' interests. ${ }^{9}$ Given the importance of technological cooperation for the successful implementation of the Protocol and the maintenance of mutual trust among its Parties, it can be anticipated that the Protocol's governing body will provide a forum for facilitating such cooperation ${ }^{10}$ and will keep this matter under review. ${ }^{11}$

The obligation to cooperate is to be interpreted and applied 'in accordance' with a series of СвD provisions. ${ }^{12}$ First of all, the СвD spells out the content of the obligation to cooperate in technical and scientific matters, which implies the promotion of international technical and scientific cooperation through the development and implementation of supportive national policies, and paying special attention to the strengthening of national capabilities through human resources development and institutional building. ${ }^{13}$ In addition, and very significantly for the Protocol provisions concerning indigenous and local communities, the obligation implies devising methods of cooperation for the development and use of indigenous and traditional technologies, including through training of personnel and exchange of experts. ${ }^{14}$ Furthermore, the obligation implies the promotion of the establishment of joint research programmes and joint ventures for technology development. ${ }^{15}$ These forms of international cooperation will likely involve bilateral cooperation, particularly with developing countries, and capacity building. ${ }^{16}$

As a complement to international cooperation, Parties are to take a series of domestic measures to provide for the effective participation by provider

For a general discussion on the duty to cooperate, see this commentary on Article 11, section 2.

$10 \quad$ See this commentary on Article 26.

11 See this commentary on Article 31.

12 Note that CBD Article 17 on the exchange of information from all publicly available sources, including the results of scientific research and traditional knowledge in combination with technologies using genetic resources, is not included in the СвD provisions referred to in this Article of the Protocol. This may arguably be explained by the desire of the drafters to avoid reference to repatriation of traditional knowledge (свр Article 17(2)). The question of the applicability of the Nagoya Protocol to the repatriation of traditional knowledge, in effect, remains open at the time of writing: see ENB, "Summary of the Eighth Meeting of the Working Group on Article 8(j) and the seventeenth meeting of the Subsidiary Body on Scientific, Technical and Technological Advice of the Convention on Biological Diversity: 7-18 October 2013", Vol. 9 No. 611, 5-6.

13 СвD Article 18(2).

14 СвD Article 18(4), emphasis added.

15 СвD Article 18(5).

16 Glowka, Burhenne-Guilmin and Synge, Guide to the Convention on Biological Diversity, op. cit., 93-94. See this commentary on Article 22. 
countries in biotechnological research, by promoting and advancing priority access to the results and benefits arising from modern biotechnologies to, and ensuring participation in biotechnological research by, Parties that provide the genetic resources for such research. ${ }^{17}$ It would thus be advisable to specify in ABS agreements that the start of biotechnological research on the provided genetic resources should be notified to the provider country so that the participation on biotechnological research can be arranged for. ${ }^{18}$

Article 23 concludes with a qualified obligation ('Where possible and appropriate') for Parties to engage in collaborative activities benefitting and taking place in Parties providing genetic resources, based on a pre-existing obligation under the СвD. ${ }^{19}$ It implicitly foresees that Parties will exercise due diligence in identifying whether the conditions exist for technology collaboration to take place in provider countries and that they will make reasonable efforts to establish these collaborations.

Overall, Article 23 allows for all types of technological collaboration amounting to fair and equitable benefit-sharing. These may include allocation of research funding, the sharing of research and development results, contribution in scientific research and development programmes, and participation in product development. ${ }^{20}$ Such types of benefit-sharing may arguably create 'a flow of goods and knowledge that opens opportunities for learning and capacity-building in developing countries.'21

\section{$3 \quad$ Technology Transfer}

As technology is often in the hands of private individuals and companies, Article 23 includes a commitment, ${ }^{22}$ rather than an obligation, for Parties

\footnotetext{
17 CBD Article 19(1-2).

18 Glowka, Burhenne-Guilmin and Synge, Guide to the Convention on Biological Diversity, op. cit., 96-97.

19 СвD Article 15(6) reads: 'Each Contracting Party shall endeavor to develop and carry out scientific research based on genetic resources provided by other Contracting Parties with the full participation of, and where possible in, such Contracting Parties,' emphasis added. Compare with Nagoya Protocol wording 'Where possible and appropriate such collaborative activities shall take place in and with a Party or the Parties providing genetic resources that is the country or are the countries of origin of such resources or a Party or Parties that have acquired the genetic resources in accordance with the Convention'.

20 Nagoya Protocol Annex, paragraphs $1(\mathrm{~h}), 2(\mathrm{a}-\mathrm{c})$ and $(\mathrm{m})$.

21 Greiber et al., Explanatory Guide, op. cit., 216.

22 Note the use of 'undertake' rather than 'shall'.
} 
to promote and encourage (i.e., at least to remove barriers to, and/or create incentives for $)^{23}$ access to, and transfer of technology ${ }^{24}$ to developing countries. This has the specific aim of enabling the development and strengthening of a sound and viable technological and scientific base for the attainment of the objectives of the $\mathrm{CBD}$ and Protocol. ${ }^{25}$ Where relevant technologies are in the hands of public entities, ${ }^{26}$ Parties have greater opportunity to provide technologies directly. The provision leaves it open to Parties to identify the specific means of implementation. These could include a domestic requirement to governmental agencies to transfer technology, the creation of economic incentives to encourage private entities to transfer technologies, the establishment of national and regional technology clearinghouses, the purchase of IPRs on behalf of another Party, or the creation of a domestic obligation upon those using public funds to develop a particular technology and make it available for transfer. ${ }^{27}$

The wording of Article 23 is based in general terms on CBD Article 16 on access to and transfer of technology. While at first sight, it may appear that the Protocol uses weaker language than the $\mathrm{CBD},{ }^{28}$ it should be recalled that Article 23 recalls CBD Article 16 and other relevant provisions in this context. ${ }^{29}$ Thus, the commitment to technology transfer under the Protocol cannot be interpreted and implemented so as to provide a lower standard than that

23 On the obligation to encourage, see this commentary on Article 9, section 1.

24 On technology transfer, see Glowka, Burhenne-Guilmin and Synge, Guide to the Convention on Biological Diversity, op. cit., 85; and UNEP-UNCTAD, Preliminary Analysis of MEA Experiences, op. cit.

25 This is yet another instance in which the Protocol pursues a holistic implementation of the three objectives of the CBD. See fn. 2 above.

26 Glowka, Burhenne-Guilmin and Synge, Guide to the Convention on Biological Diversity, op. cit., $84-85$.

27 Ibid., 85 and 90.

28 CBD Article 16(1) reads 'Each Contracting Party... undertakes... to provide and/or facilitate access for and transfer to other Contracting Parties of technologies' (emphasis added); whereas the Protocol only refers to a commitment to 'promote and encourage' technology transfer. We are grateful to Tomme Young for drawing our attention to this point.

29 This interpretation appears to offer the only justification for the crammed drafting of Article 23, as three different obligations are clustered in the same paragraph instead of being divided into three separate paragraphs. It can therefore be argued that the opening proviso 'in accordance with Articles 15, 16, 18 and 19 of the Convention' applies to the entirety of Article 23. This interpretation is also proposed by Greiber et al., Explanatory Guide, op. cit., 216. 
established under the Convention. In addition, Protocol Parties as CBD Parties will continue to be bound by the CBD provisions in this regard.

Interpreted in the light of the relevant provisions of the CBD, Article 23 requires Parties to adopt domestic measures that provide, or at least facilitate, access to technologies that make use of genetic resources, including biotechnologies, as well as technologies that are relevant for conservation and sustainable use. ${ }^{30}$ This has to be arranged under fair and most favorable terms, including on concessional and preferential terms if mutually agreed, when developing countries are concerned. ${ }^{31}$ Both provider and receiver countries have an obligation to ensure that the transferred technology does not cause significant damage to the environment. ${ }^{32}$

Notably, the Protocol 'buries' a solitary reference to intellectual property in relation to technology transfer in its Annex among the possible monetary and non-monetary benefits. ${ }^{33}$ There, reference is made to transferring technologies under fair and most favorable terms, including on concessional and preferential terms where agreed. ${ }^{34}$ Such reference replicates wording common to other multilateral environmental agreements. ${ }^{35}$ As opposed to the Protocol, the СвD explicitly acknowledges that technology often is in private hands. It thus obliges Parties to take domestic measures targeting the private sector so as to facilitate access to, and joint development of, technology with governmental institutions and the private sector of developing countries. ${ }^{36}$ It also addresses explicitly the relevance of IPRs, by requiring that domestic legislation provide

30 Свр Article 16(1). Note, however, that Свр Article 16 was one of the most controversial ones in the negotiations of the Convention and that '[c]ircular cross-referencing introduces decided ambiguity that opens the door to differing interpretations.' See Glowka, Burhenne-Guilmin and Synge, Guide to the Convention on Biological Diversity, op. cit., 84.

31 CBD Article 16(2).

32 свD Article 16(1). Glowka, Burhenne-Guilmin and Synge, Guide to the Convention on Biological Diversity, op. cit., 85-6.

33 See this commentary on Article 5, section 6.

34 Nagoya Protocol Annex, paragraph 2(f).

35 CBD Article 16(2); UNFCCC Articles 4(1)(c) and (5); and Montreal Protocol on Substances that Deplete the Ozone Layer (Montreal, 16 September 1987, in force 1 January 1989) 1522 unts 28 (hereinafter, Montreal Protocol), Article 10(A). See also Glowka, BurhenneGuilmin and Synge, Guide to the Convention on Biological Diversity, op. cit., 86; and more generally: CBD, UNCTAD and wiPo Secretariats, The Role of Intellectual Property Rights in Technology Transfer in the Context of the Convention on Biological Diversity, 2007, accessed 30 November 2013, <www.cbd.int/doc/meetings/ttc/egttstc-02/other/egttstc-02-othtechstudy-en.pdf $>$.

$36 \quad$ свD Article 16(4). 
access to technologies also when protected by IPRs, on the basis of MAT. ${ }^{37}$ It subjects access to such technology to terms that balance the need for transfer with the adequate and effective protection of intellectual property. ${ }^{38}$ It further calls for international cooperation to ensure that IPRs are supportive of the objectives of the Convention. ${ }^{39}$ These provisions are also applicable in the context of the Protocol's implementation.

In implementing Article 23, Parties may find concrete guidance in the СвD work programme on technology transfer and scientific and technological cooperation, which was adopted by consensus. ${ }^{40}$ Accordingly, Parties should establish an enabling environment for technology transfer in providing and receiving countries by creating an institutional, administrative, legislative and policy structures for the private and public sector not only for the transfer of technology, but also for the adaptation of transferred technology. Parties are also to remove barriers to technology transfer that exist in their domestic frameworks, and that are inconsistent with international law. In addition, Parties should conceive technology transfer not as a one-off, unilateral endeavor, but as part of an integrated, long-term scientific and technological cooperation effort, thereby creating the conditions for lasting participation by provider countries with a view to increasing their capacities and information base, as well as adding value at the local level. ${ }^{41}$

Overall, the commitment to technology transfer must be implemented in good faith to ensure fair and equitable benefit-sharing, ${ }^{42}$ as required to realize the objective of the Protocol. ${ }^{43}$ Such commitment requires every reasonable effort, ${ }^{44}$ even before knowing how the genetic resources will be used. ${ }^{45}$ These efforts can be facilitated through information-sharing under the ABS

37 свD Article 16(3).

38 The reference to 'adequate and effective protection' was meant to refer implicitly to protection under TriPs: Glowka, Burhenne-Guilmin and Synge, Guide to the Convention on Biological Diversity, op. cit., 86-87.

39 свD Articles 16(4), 16(2) and 16(5).

40 "Programme of work on technology transfer and technological and scientific cooperation" in СвD Decision 7/29, "Transfer of technology and technology cooperation (Articles 16 to 19)" (13 April 2004) un Doc unep/cbd/cop/7/21, Annex. See Morgera and Tsioumani, "Evolution of Benefit-Sharing," op. cit., 153.

41 свр Decision 7/29, paragraph 2. See Greiber et al., Explanatory Guide, op. cit., 217.

42 свD Article 15(7). Greiber et al., Explanatory Guide, op. cit., 216.

43 See this commentary on Article 2, sections 1-2.

44 Glowka, Burhenne-Guilmin and Synge, Guide to the Convention on Biological Diversity, op. cit., 97.

45 Ibid., 83. 
Clearinghouse. ${ }^{46}$ They may also receive financial support, including by meeting the agreed full incremental costs of establishing technological cooperation and ensuring technology transfer through the financial mechanism of the Protocol. ${ }^{47}$

46 Greiber et al., Explanatory Guide, op. cit., 216. See this commentary on Article 14, section 3. Compare свD Article 18(3).

47 Note in fact that СвD Article 19 on technology transfer makes reference to the СвD provisions on financial solidarity (Articles 20-21). See Glowka, Burhenne-Guilmin and Synge, Guide to the Convention on Biological Diversity, op. cit., 83 and 86. See also this commentary on Article 25, section 2. 